\title{
Morphological sexing of passerines: not valid over larger geographical scales
}

\author{
Heike Ellrich • Volker Salewski • Wolfgang Fiedler
}

Received: 13 November 2008/Revised: 23 October 2009/Accepted: 31 October 2009/Published online: 27 November 2009

(C) The Author(s) 2009. This article is published with open access at Springerlink.com

\begin{abstract}
Sex determination of birds is important for many ecological studies but is often difficult in species with monomorphic plumage. Morphology often provides a possibility for sex determination, but the characters need to be verified. We tested whether five passerine species can be sexed according to standard morphological measurements applying a forward logistic regression with sex determined by molecular analysis as the dependent variable. Furthermore, we tested whether the results can be used on a larger geographic scale by applying morphological sexing methods gained by similar studies from other regions to our data set. Of the five species of this study only Garden Warblers Sylvia borin could not be sexed morphologically. In the Robin Erithacus rubecula, $87.2 \%$ of all individuals were sexed correctly. For Reed Warblers Acrocephalus scirpaceus, Willow Warblers Phylloscopus trochilus and Reed Buntings Emberiza schoeniclus, the respective values were $77.6,89.4$ and $86.4 \%$. When the logistic regression functions from similar studies on Robins and Reed Buntings in Denmark and Scotland were applied to the birds from south-western Germany, they performed less well compared to the original dataset of these studies and compared to the logistic regression function of our own study. The same was the case for Willow Warblers when a wing length criterion used in Great Britain was applied to the birds of our study. These discrepancies may have several explanations: (1) the models are optimised for the dataset from which they were extracted, (2) inter-ringer
\end{abstract}

Communicated by F. Bairlein.

H. Ellrich · V. Salewski $(\bowtie) \cdot$ W. Fiedler

Vogelwarte Radolfzell at the Max-Planck Institute

of Ornithology, Schlossallee 2, 78315 Radolfzell, Germany

e-mail: salewski@orn.mpg.de variation in measurements, (3) the use of different age cohorts, (4) different morphology due to different habitat availability around the study site, or, most likely, (5) different morphology due to different migratory behaviour. We recommend that morphological sex differentiation methods similar to this study (1) be only used population specific, (2) only with one age cohort and (3) to adjust the extracted equations from time to time.

Keywords Passerines · Morphology $\cdot$ Sex determination · PCR

\section{Introduction}

Sex determination of birds is important in many ecological studies but sex differentiation is difficult in species with monomorphic plumage even when the concerned individuals are captured. During the breeding season, most individuals of many species can be sexed either due to the presence of an incubation patch, most pronounced in females, or the cloacal protuberance in males (Drost 1938; Svensson 1992). However, during the non-breeding season, these characters are invalid. Nevertheless, sexing birds in the non-breeding season is desirable especially for migration studies which analyse differential migration phenomena, i.e. sex-specific different migration phenologies, migration routes, wintering areas and wintering ecology with respect to differential habitat use or territorial behaviour.

Many passerine species which are monomorphic in plumage characters show a distinct size dimorphism with males usually being larger compared to females. This size dimorphism is often expressed by longer wings, longer tarsi or a higher body mass (Svensson 1992). These 
measurements are taken routinely at most ringing stations collecting data for bird migration studies on a large scale (Bairlein 1995). However, although there is often a statistically significant difference in the mean values of a morphological character between the sexes, there is also an overlap of varying degrees in the measurements, which leads to uncertainties when relying on morphological sex determination alone. Furthermore, to establish morphology as a reliable means for sex determination, the respective characters have to be verified by testing them on a sufficiently high number of individuals of explicitly known sex.

In former times, researchers sometimes sacrificed a number of individuals of the species under study for sex determination (Kalchreuter 1971). An ethically sounder, but nevertheless invasive method, is laparotomy when the gonads are checked through a cut into the body cavity of the living bird. The cut heals within several days but care has to be taken to avoid injuries of the liver, the kidney or the digestive tract, and there is always the risk of infections (Berthold 1969). Morgan (2005) discussed the possibility of analysing multi-modal distributions of morphological characters to differentiate sexes accordingly. This approach was used, e.g., by Catry et al. (2005) who separated male and female Chiffchaffs Phylloscopus collybita based on the bi-modal distribution of wing length. However, although this method is based on sound assumptions, there is no independent verification that the individuals classified as males or females do in fact belong to the respective sex cohort. Relatively unproblematic and reliable is taking a blood sample for later molecular sex determination in the laboratory (Griffiths et al. 1998), but this method is not practicable for all mist-netted birds at field stations where sometimes hundreds of birds are captured daily. Furthermore, in many countries blood sampling is more restricted by animal welfare legislation than trapping and ringing of birds.

However, many recent authors who wanted to verify sex determination by morphological measurements used molecular methods for sex determination (Griffiths et al. 1998) of a sub-sample of the species under study (Madsen 1997; Hipkiss 2007; Ottvall and Gunnarsson 2007). The sex is then used as the dependent variable in either a discriminant analysis or a logistic regression with a number of morphological measurements as explaining variables to identify the variables associated with the sex of the species under study. In recent years, these methods have been used to investigate morphological variables which can be used for sex determination in a number of non-passerine and passerine bird species (Madsen 1997; Walton and Walton 1999; Bertellotti et al. 2002; Campos et al. 2005; Hipkiss 2007; Ottvall and Gunnarsson 2007; Shealer and Clearey 2007). Although these methods can lead to reliable sex determination of the population under study, its general application for the species concerned has two caveats: First, the statistical models are selected to fit a particular sample. It will therefore fit the sample better than it will the entire population from which it is drawn or a sample from another population. Second, there are intra-specific differences in morphology due to different migration distances or other ecological factors (temperature, habitat) mainly varying across latitudes. In migratory species, those populations with a relatively longer migration distance usually have longer wings compared to populations with relatively shorter migration distance as shown, e.g., for the Willow Warbler (Lindström et al. 1996) or the Blackcap Sylvia atricapilla (Fiedler 2005).

In the present study, we want to test first whether the sex of first year individuals of five common passerine species which are captured regularly at a constant effort mist-netting site in south-western Germany can be sexed reliably with standard morphological measurements. For this purpose, we used a set of morphological variables in connection with molecular sex determination to verify the validity of morphological sexing. Second, we compare our results with similar studies to test whether morphological sexing is reliable with the same criteria over a larger geographical range. We therefore use only standard measurements which are taken within many studies and thus can be compared with the results of other stations.

\section{Methods}

Target species and morphological data

Birds were captured as part of a monitoring programme on the peninsula Mettnau $\left(47.729^{\circ} \mathrm{N}, 8.998^{\circ} \mathrm{E}\right)$, Lake Constance, near Radolfzell in south-western Germany. Since 1972, between 30 June and 6 November, mistnetting follows standardised methods (for details, see Berthold and Schlenker 1975). The early start of the autumn netting season enables the capture of local breeding birds as well as migrating individuals of most species during the entire autumn migration period. The proportions of local birds and of birds on passage are, however, unknown. All captured birds are identified to species, ringed and aged following the criteria given in Svensson (1992) and Jenni and Winkler (1994). Standard measurements taken are: (1) feather length, i.e. the length of the third outermost primary feather (hereafter: feather) following Berthold and Friedrich (1979); (2) wing length (hereafter: wing) according to method "maximum length" in Svensson (1992); and (3) tarsus length (hereafter: tarsus) according to the "alternative method" in Svensson (1992, Fig. 18b); feather and wing length were measured with a precision of $0.5 \mathrm{~mm}$ and tarsus with a precision of 
$0.1 \mathrm{~mm}$; and (4) body mass is taken with an electronic balance with a precision of $0.1 \mathrm{~g}$. For every bird, the fat in the furcula pit was scored on an ordinal nine-digit scale from 0 (no fat) to 8 (entire flight muscle covered with fat) according to Kaiser (1993). Furthermore, the thickness of the flight muscle was estimated on an ordinal four-digit scale according to Bairlein (1995). As both estimates showed low variation between individuals (fat scored 0,1 or 2 in about $87 \%$; muscle scored 1 or 2 in about $88 \%$ in all birds, respectively) we did not consider fat and muscle scores in the further analyses. Therefore, our study remains comparable to other studies which also did not consider fat and muscle scores (e.g. Walton and Walton 1999). All birds in this study were measured between 30 June and 27 September 2007 by H. Ellrich and only those individuals for which all four measurements were available were considered.

Target species were selected according to the a priori expectation of sufficient numbers mist-netted for the analyses based on experience from previous years. Furthermore, only those species were selected in which sex of first year birds before juvenile moult cannot be determined in the hand according to plumage characters. The selected species were (sample size in brackets): Robin Erithacus rubecula (94), Reed Warbler Acrocephalus scirpaceus (147), Garden Warbler Sylvia borin (79), Willow Warbler Phylloscopus trochilus (47) and Reed Bunting Emberiza schoeniclus (44). Morphology of the flight apparatus and body mass of passerines varies with age, i.e. first year birds in many species have shorter wings and a lower body mass compared to older birds (e.g. Alatalo et al. 1984; Schmitz and Steiner 2006; Markovets et al. 2008). For some passerine species, it has been shown that variation in wing length also occurs between different age cohorts after the first primary moult, i.e. wing length increases with age (Merom et al. 1999; Dale et al. 2002). Furthermore, the consideration of first year birds only excludes birds in primary moult. The consideration of birds more than one year old could therefore lead to erroneous results. It is in general not possible to age birds of the species considered in this study when they are more than one year of age, i.e. after their first primary moult. Therefore, only fully grown first year birds were included in the analyses. Every bird was considered only once.

\section{Molecular sexing}

Molecular sexing followed Griffiths et al. (1998) using a modified PCR amplification of the CHD genes. For the amplification, two different primer pairs were chosen: the P2 (5'-TCT GCA TCG CTA AAT CCT TT- $\left.3^{\prime}\right)$ and the P8 (5'-CTC CCA AGG ATG AG (AG) AA (CT) TG-3') primers (Griffiths et al. 1998) were used for DNA amplification in the Garden Warbler, Reed Warbler, Willow Warbler and Reed Bunting and the primer pair 3,007 (5'-TAC ATA CAG GCT CTA CTC CT- ${ }^{\prime}$ ) and 3,112 (5'-CCC CTT CAG GTT TAA AA-3') was used for amplification in the Robin (Ellegren and Fridolfsson 1997). PCR amplification was carried out in a total volume of $10 \mu \mathrm{l}$. The PCR was performed in a 2720 Thermal cycler (Applied Biosystems). An initial denaturation step at $94^{\circ} \mathrm{C}$ for $3 \mathrm{~min}$ was followed by 35 cycles of $94^{\circ} \mathrm{C}$ for $30 \mathrm{~s}, 50^{\circ} \mathrm{C}$ for $30 \mathrm{~s}, 72^{\circ} \mathrm{C}$ for $45 \mathrm{~s}$ and $72^{\circ} \mathrm{C}$ for $90 \mathrm{~s}$ for both primer pairs. A final cooling period of $4^{\circ} \mathrm{C}$ completed the program. PCR products were separated by electrophoresis on $2 \%$ agarose gels. The gel was stained with SybrGold gel stain (Molecular Probes).

\section{Statistics}

All morphological variables were tested for a normal distribution with a one-sample Kolmogorov-Smirnov-test. Then, a forward conditional logistic regression was used to extract morphological variables which could be used to discriminate between the sexes. In forward conditional regressions, removal testing is based on the probability of likelihood-ratio statistics and a variable is entered in the regression when $P<0.05$ and a variable is removed when $P>0.1$. In the logistic regression, sex revealed by the molecular analysis was used as the dependent variable and the morphological measurements feather, wing and tarsus as well as body mass were covariates. The sexes were coded " 0 " for male and " 1 " for female for the regression. The goodness-of-fit of the logistic regression was tested with a Hosmer-Lemeshov-test (Hosmer and Lemeshov 1989).

With the linear logistic function retrieved from the model

$d=\alpha+\beta_{1} x_{1}+\beta_{2} x_{2}+\cdots+\beta_{i} x_{i}$

where $\alpha$ is a constant and $\beta_{1,2}, \ldots$, i regression coefficients of the predictor variables $x_{1,2}, \ldots, \mathrm{i}$, an individual bird with certain predictor variables will be classified as being male $(d<0)$ or female $(d>0)$. The probability that a bird with a given morphology is female can be estimated according to:

$p_{\text {female }}=e^{d} / 1+e^{d}$

where $d$ is the logistic function and $e$ is the base of natural logarithms, $\sim 2.718$. The probability of being male is: $p_{\text {male }}=1-p_{\text {female }}$.

Birds migrating through the study area from more northern latitudes may have a different wing morphology compared to resident conspecifics because of adaptation to different migration distance (Leisler and Winkler 2003; Fiedler 2005). Therefore, we tested whether day of the 
season is associated with the morphological measurements with a one-way ANOVA with feather, wing, tarsus and body mass as dependent variables and day of the season (30 June $=1,1$ July $=2$, etc.) as a factor.

Due to the low sample size for some species, we refrained from splitting the sample to do the analyses with one part of the sample and test its accuracy with the second half of the sample. SPSS 12.0 was used for all statistical analysis. The accepted significance level was $P<0.05$.

\section{Results}

Molecular sexing

Molecular sexing revealed that the sample included 54 male and 40 female Robins, 68/79 Reed Warblers, 47/33 Garden Warblers, 24/23 Willow Warblers and 24/20 Reed Buntings. In all species, the proportion of the two sexes did not differ significantly from an even ratio (binomial test, $P>0.1)$.

\section{Morphological sexing}

All morphological variables were normally distributed for both sexes in all species (Kolmogorov-Smirnoff test, $P>0.05)$. In all measurements with significant intra-specific inter-sexual differences male birds showed the higher values, i.e. were the larger sex (Table 1).

A two-step forward conditional logistic regression with sex as revealed by molecular sexing as the dependent variable and the morphological variables wing, feather and tarsus as well as body mass as covariates included wing length and feather length (Nagelkerke- $R^{2}: 0.669$, HosmerLemeshow GOF: $P=0.588$ ) for the Robin. With these two variables, $87.2 \%$ (males: $88.9 \%$, females: $85.0 \%$ ) of the
Robins could be sexed correctly with the equation $d=120.585-1.161 \times$ wing $-0.655 \times$ feather (Table 2; Fig. 1a). In Reed Warblers, wing and tarsus were included in a two-step logistic regression (Nagelkerke- $R^{2}$ : 0.389; Hosmer-Lemeshow GOF: $P=0.145$ ). With the function $d=72.765-1.367 \times$ tarsus $-0.638 \times$ wing, the sex could be predicted correctly for $77.6 \%$ (males: $73.5 \%$, females: $81.0 \%$ ) of all individuals (Table 2; Fig. 1b). In Willow Warblers, only wing was included in the analysis (Nagelkerke- $R^{2}$ : 0.803 ; Hosmer-Lemeshow GOF: $P=0.416$ ), and for $89.4 \%$ (males: $91.7 \%$, females: $87.0 \%$ ) of the birds the sex could be predicted correctly with the regression equation $d=97.233-1.486 \times$ wing (Table 2; Fig. 1c). For the Reed Bunting, $86.4 \%$ (males: $87.5 \%$, females: $85.0 \%$ ) of all individuals could be sexed correctly according to a one-step logistic regression (Nagelkerke- $R^{2}$ : 0.721; Hosmer-Lemeshow GOF: $P=0.981$ ) with the function $d=75.423-0.98 \times$ wing (Table 2; Fig. 1d). The Garden Warbler was the only species for which none of the variables met the conditions for the inclusion in a conditional forward regression. Therefore, it is not possible to sex first year Garden Warblers using the measurements and the statistical methods applied in this study.

None of the selected variables was significantly associated with capture date (ANOVA: $P>0.05$; power on the 0.05 significance level for the Robin: wing $=0.855$, feather $=0.797$; Reed Warbler: $\quad$ wing $=0.507$, tarsus $=0.292$; Willow Warbler: wing $=0.804$; Reed Bunting: wing $=0.595$ ). Therefore, the extracted variables could be used throughout the respective trapping periods.

In addition to the mere classification of a bird as being male or female according to the $\mathrm{d}$ values calculated from Eq. 1, the probability that a bird with a certain combination of morphological measurements is female was estimated according to Eq. 2. In the Robin, the morphological criteria for a $>95 \%$ probability of belonging to the correct sex was

Table 1 Morphological measurements of five passerine species

\begin{tabular}{|c|c|c|c|c|c|c|c|c|c|c|}
\hline \multirow[t]{2}{*}{ Species } & \multirow[t]{2}{*}{ Sexes $(M / F)$} & & \multicolumn{2}{|l|}{ Mass } & \multicolumn{2}{|l|}{ Tarsus } & \multicolumn{2}{|l|}{ Wing } & \multicolumn{2}{|l|}{ Feather } \\
\hline & & & Male & Female & Male & Female & Male & Female & Male & Female \\
\hline \multirow[t]{2}{*}{ Robin } & \multirow[t]{2}{*}{$54 / 40$} & Mean & 16.31 & 15.98 & 25.16 & 25.18 & $74.68 * * *$ & $72.24 * * *$ & $55.69 * * *$ & $53.48 * * *$ \\
\hline & & SD & 0.93 & 0.78 & 0.68 & 0.74 & 1.44 & 1.12 & 1.27 & 1.02 \\
\hline \multirow[t]{2}{*}{ Reed Warbler } & \multirow[t]{2}{*}{$68 / 79$} & Mean & 11.16 & 11.24 & $22.63 * * *$ & $22.02 * * *$ & $66.58 * * *$ & $65.27 * * *$ & $50.48 * * *$ & $49.40 * * *$ \\
\hline & & SD & 0.63 & 0.62 & 0.65 & 0.56 & 1.36 & 1.32 & 1.383 & 1.32 \\
\hline \multirow[t]{2}{*}{ Garden Warbler } & \multirow[t]{2}{*}{$47 / 33$} & Mean & 18.76 & 18.82 & 19.78 & 19.63 & 78.16 & 77.76 & 58.53 & 58.24 \\
\hline & & SD & 1.67 & 2.08 & 0.70 & 0.70 & 1.86 & 2.58 & 1.50 & 2.00 \\
\hline \multirow[t]{2}{*}{ Willow Warbler } & \multirow[t]{2}{*}{$24 / 23$} & Mean & $8.88 *$ & $8.13 *$ & $19.46^{* * *}$ & $18.51 * * *$ & $67.69 * * *$ & $63.39 * * *$ & $50.90 * * *$ & $47.76 * * *$ \\
\hline & & SD & 0.69 & 0.85 & 0.58 & 0.55 & 1.55 & 1.55 & 1.50 & 1.48 \\
\hline \multirow[t]{2}{*}{ Reed Bunting } & \multirow[t]{2}{*}{$24 / 20$} & Mean & $18.20 *$ & $16.55^{*}$ & $19.62 *$ & $18.96^{*}$ & $79.56^{* * *}$ & $74.90 * * *$ & $60.35^{* * *}$ & $56.20 * * *$ \\
\hline & & SD & 1.58 & 1.29 & 0.64 & 0.71 & 1.97 & 1.96 & 1.69 & 1.94 \\
\hline
\end{tabular}

$* P<0.05$; *** $P<0.001$ : significant inter-sexual differences according to a 2 -tailed $t$ test with equal variances 
Table 2 Results of a logistic regression with sex as the dependent variable and all morphological characters as covariates

\begin{tabular}{llrrrr}
\hline Species & & \multicolumn{1}{l}{ S } & \multicolumn{1}{l}{ Wald } & \multicolumn{1}{l}{$P$} \\
\hline Robin & Mass & -0.214 & 0.355 & 0.364 & 0.546 \\
& Tarsus & 0.760 & 0.462 & 2.709 & 0.100 \\
& Wing & -1.376 & 0.488 & 7.952 & 0.005 \\
& Feather & -0.588 & 0.421 & 1.951 & 0.162 \\
Reed Warbler & Constant & 117.070 & 26.317 & 19.789 & $<0.001$ \\
& Mass & 0.115 & 0.334 & 0.119 & 0.731 \\
& Tarsus & -1.362 & 0.345 & 15.629 & $<0.001$ \\
& Wing & -0.513 & 0.222 & 5.344 & 0.021 \\
& Feather & -0.165 & 0.199 & 0.685 & 0.408 \\
& Constant & 71.331 & 13.868 & 26.457 & $<0.001$ \\
Garden Warbler & Mass & 0.086 & 0.138 & 0.394 & 0.530 \\
& Tarsus & -0.324 & 0.376 & 0.740 & 0.390 \\
& Wing & -0.070 & 0.207 & 0.114 & 0.735 \\
& Feather & 0.002 & 0.261 & $<0.001$ & 0.995 \\
& Constant & 9.775 & 9.374 & 1.087 & 0.297 \\
Willow Warbler & Mass & -0.118 & 0.703 & 0.028 & 0.867 \\
& Tarsus & -0.618 & 1.015 & 0.371 & 0.543 \\
& Wing & -1.389 & 0.626 & 4.917 & 0.027 \\
& Feather & -0.034 & 0.542 & 0.004 & 0.956 \\
& Constant & 105.207 & 35.368 & 8.849 & 0.003 \\
& Mass & 0.152 & 0.406 & 0.139 & 0.709 \\
& Tarsus & -0.786 & 0.831 & 0.894 & 0.344 \\
& Wing & -0.389 & 0.460 & 0.713 & 0.399 \\
& Constant & 87.646 & 26.341 & 11.071 & 0.001 \\
\hline \multirow{5}{*}{ Reed Bunting } & -0.776 & 0.568 & 1.871 & 0.171 \\
& & & & & \\
& Mathe &
\end{tabular}

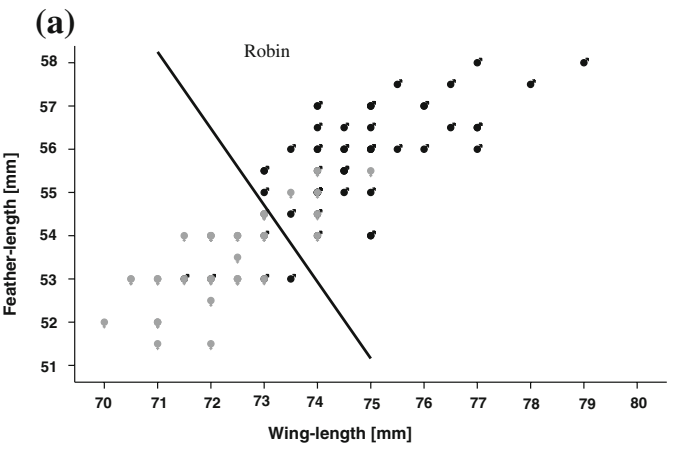

(c)

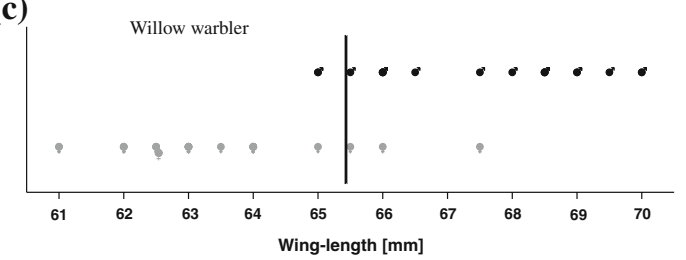

Fig. 1 Morphometric sex determination. a Robin, b Reed Warbler, c Willow Warbler, $\mathbf{d}$ Reed Bunting. The morphometric variables were extracted by a forward conditional logistic regression. $q$ and $\hat{\sigma}$ indicate the sex of the birds according to molecular sexing. Note that found in $11(27.5 \%)$ of females and in $20(37 \%)$ of males. The respective values for a $>90 \%$ probability were 16 (40.0\%) for females and $29(53.7 \%)$ for males (Table 3a). In the other species (Table $3 b-d)$, the respective values were for Reed Warblers: $>95 \%$ correct probability for 8 females $(10.1 \%)$ and 3 males $(4.4 \%)$ and $>90 \%$ correct probability for 14 females (17.7\%) and 8 males $(11.8 \%)$, for Willow Warblers: $>95 \%$ correct probability for 13 females $(56.5 \%)$ and 17 males $(70.8 \%)$ and $>90 \%$ correct probability for 14 females $(60.9 \%)$ and 17 males $(70.8 \%)$ and for Reed Buntings: $>95 \%$ correct probability for 4 females $(20 \%)$ and 15 males $(62.5 \%)$ and $>90 \%$ correct probability for 8 females $(40 \%)$ and 17 males $(70.8 \%)$. All birds with a $>90 \%$ probability to be sexed correctly were in fact sexed correctly.

Comparison with studies from other regions

There are two comparable studies (Madsen 1997; Walton and Walton 1999) about the sexing of some of our target species from other regions. Additionally, there are several other hints about sexing of these species where the exact methods of verification were not always known. Below, we apply the characters mentioned in former studies to verify their validity for the sample considered in this study.

Madsen (1997) studied Robins during the breeding season and during autumn migration in Denmark and used molecular sexing of 138 birds of mixed age to verify morphological sex determination. The author was able to

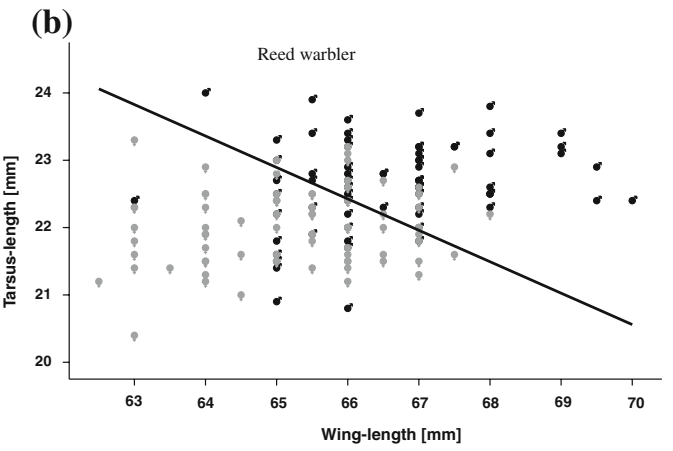

(d)

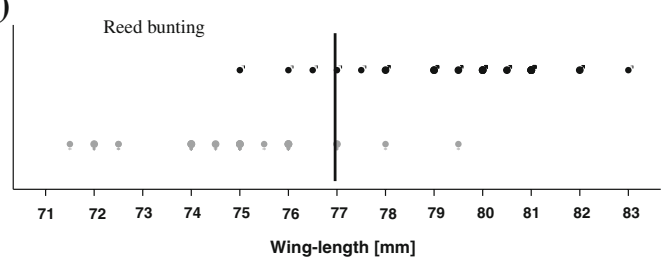

one symbol can indicate several individuals. The line shows the separation of the sexes according to the results of logistic regression. Birds below/to the left of the line were classified as females and birds abovelto the right of the line were classified as males. 
Table 3 Probability of a bird with a certain combination of morphological variables being female

(a) Robin

\begin{tabular}{|c|c|c|c|c|c|c|c|c|c|c|c|c|c|c|c|}
\hline & \multicolumn{14}{|c|}{ Feather-length [mm] } \\
\hline & & 51.5 & 52.0 & 52.5 & 53.0 & 53.5 & 54.0 & 54.5 & 55.0 & 55.5 & 56.0 & 56.5 & 57.0 & 57.5 & 58.0 \\
\hline \multirow{19}{*}{ 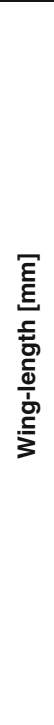 } & 70.0 & 0.996 & 0.995 & 0.993 & 0.990 & 0.986 & 0.981 & 0.974 & 0.964 & 0.951 & 0.933 & 0.909 & 0.879 & 0.839 & 0.790 \\
\hline & 70.5 & 0.993 & 0.991 & 0.987 & 0.982 & 0.976 & 0.967 & 0.954 & 0.938 & 0.915 & 0.886 & 0.849 & 0.802 & 0.745 & 0.678 \\
\hline & 71.0 & 0.988 & 0.984 & 0.977 & 0.969 & 0.957 & 0.942 & 0.921 & 0.894 & 0.858 & 0.814 & 0.759 & 0.694 & 0.620 & 0.541 \\
\hline & 71.5 & 0.979 & 0.971 & 0.960 & 0.946 & 0.926 & 0.901 & 0.867 & 0.825 & 0.772 & 0.710 & 0.638 & 0.559 & 0.478 & 0.397 \\
\hline & 72.0 & 0.963 & 0.949 & 0.931 & 0.907 & 0.876 & 0.835 & 0.785 & 0.725 & 0.655 & 0.578 & 0.496 & 0.415 & 0.339 & 0.270 \\
\hline & 72.5 & 0.936 & 0.913 & 0.883 & 0.845 & 0.797 & 0.739 & 0.672 & 0.596 & 0.515 & 0.434 & 0.355 & 0.284 & 0.223 & 0.171 \\
\hline & 73.0 & 0.891 & 0.855 & 0.809 & 0.753 & 0.688 & 0.613 & 0.534 & 0.452 & 0.373 & 0.300 & 0.236 & 0.182 & 0.138 & 0.104 \\
\hline & 73.5 & 0.820 & 0.767 & 0.703 & 0.631 & 0.552 & 0.470 & 0.390 & 0.316 & 0.250 & 0.193 & 0.147 & 0.111 & 0.082 & 0.061 \\
\hline & 74.0 & 0.719 & 0.648 & 0.570 & 0.489 & 0.408 & 0.332 & 0.264 & 0.205 & 0.157 & 0.118 & 0.088 & 0.065 & 0.048 & 0.035 \\
\hline & 74.5 & 0.589 & 0.508 & 0.426 & 0.349 & 0.278 & 0.218 & 0.167 & 0.126 & 0.094 & 0.070 & 0.051 & 0.038 & 0.027 & 0.020 \\
\hline & 75.0 & 0.445 & 0.366 & 0.294 & 0.231 & 0.178 & 0.135 & 0.101 & 0.075 & 0.055 & 0.040 & 0.029 & 0.021 & 0.015 & 0.011 \\
\hline & 75.5 & 0.309 & 0.244 & 0.189 & 0.144 & 0.108 & 0.080 & 0.059 & 0.043 & 0.032 & 0.023 & 0.017 & 0.012 & 0.009 & 0.006 \\
\hline & 76.0 & 0.200 & 0.153 & 0.115 & 0.086 & 0.063 & 0.046 & 0.034 & 0.025 & 0.018 & 0.013 & 0.009 & 0.007 & 0.005 & 0.004 \\
\hline & 76.5 & 0.123 & 0.092 & 0.068 & 0.050 & 0.036 & 0.027 & 0.019 & 0.014 & 0.010 & 0.007 & 0.005 & 0.004 & 0.003 & 0.002 \\
\hline & 77.0 & 0.073 & 0.054 & 0.039 & 0.029 & 0.021 & 0.015 & 0.011 & 0.008 & 0.006 & 0.004 & 0.003 & 0.002 & 0.002 & 0.001 \\
\hline & 77.5 & 0.042 & 0.031 & 0.022 & 0.016 & 0.012 & 0.008 & 0.006 & 0.004 & 0.003 & 0.002 & 0.002 & 0.001 & 0.001 & 0.001 \\
\hline & 78.0 & 0.024 & 0.017 & 0.013 & 0.009 & 0.007 & 0.005 & 0.003 & 0.002 & 0.002 & 0.001 & 0.001 & 0.001 & 0.000 & 0.000 \\
\hline & 78.5 & 0.014 & 0.010 & 0.007 & 0.005 & 0.004 & 0.003 & 0.002 & 0.001 & 0.001 & 0.001 & 0.001 & 0.000 & 0.000 & 0.000 \\
\hline & 79.0 & 0.008 & 0.006 & 0.004 & 0.003 & 0.002 & 0.001 & 0.001 & 0.001 & 0.001 & 0.000 & 0.000 & 0.000 & 0.000 & 0.000 \\
\hline
\end{tabular}

(b) Reed warbler

\begin{tabular}{|c|c|c|c|c|c|c|c|c|c|c|c|c|c|c|c|c|c|}
\hline & & \multicolumn{16}{|c|}{ Wing-length [mm] } \\
\hline & & 62.5 & 63.0 & 63.5 & 64.0 & 64.5 & 65.0 & 65.5 & 66.0 & 66.5 & 67.0 & 67.5 & 68.0 & 68.5 & 69.0 & 69.5 & 70.0 \\
\hline \multirow{19}{*}{ 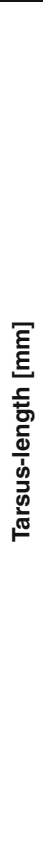 } & 20.4 & 0.993 & 0.991 & 0.987 & 0.983 & 0.977 & 0.968 & 0.956 & 0.941 & 0.921 & 0.894 & 0.860 & 0.817 & 0.764 & 0.702 & 0.631 & 0.554 \\
\hline & 20.6 & 0.991 & 0.988 & 0.984 & 0.978 & 0.969 & 0.958 & 0.944 & 0.924 & 0.898 & 0.865 & 0.823 & 0.772 & 0.711 & 0.642 & 0.566 & 0.486 \\
\hline & 20.8 & 0.989 & 0.984 & 0.979 & 0.971 & 0.960 & 0.946 & 0.927 & 0.902 & 0.870 & 0.830 & 0.780 & 0.721 & 0.652 & 0.577 & 0.498 & 0.419 \\
\hline & 21.0 & 0.985 & 0.979 & 0.972 & 0.962 & 0.948 & 0.930 & 0.906 & 0.875 & 0.836 & 0.788 & 0.730 & 0.662 & 0.588 & 0.509 & 0.430 & 0.354 \\
\hline & 21.2 & 0.980 & 0.973 & 0.963 & 0.950 & 0.933 & 0.910 & 0.880 & 0.842 & 0.795 & 0.739 & 0.673 & 0.599 & 0.520 & 0.441 & 0.364 & 0.294 \\
\hline & 21.4 & 0.974 & 0.965 & 0.952 & 0.936 & 0.914 & 0.885 & 0.848 & 0.803 & 0.747 & 0.682 & 0.610 & 0.532 & 0.452 & 0.375 & 0.304 & 0.241 \\
\hline & 21.6 & 0.967 & 0.955 & 0.938 & 0.917 & 0.890 & 0.854 & 0.810 & 0.756 & 0.692 & 0.621 & 0.543 & 0.464 & 0.386 & 0.313 & 0.249 & 0.194 \\
\hline & 21.8 & 0.956 & 0.941 & 0.921 & 0.894 & 0.860 & 0.817 & 0.764 & 0.702 & 0.631 & 0.554 & 0.475 & 0.397 & 0.323 & 0.258 & 0.202 & 0.155 \\
\hline & 22.0 & 0.944 & 0.924 & 0.898 & 0.865 & 0.823 & 0.772 & 0.711 & 0.642 & 0.566 & 0.486 & 0.408 & 0.333 & 0.267 & 0.209 & 0.161 & 0.122 \\
\hline & 22.2 & 0.927 & 0.902 & 0.870 & 0.830 & 0.780 & 0.721 & 0.652 & 0.577 & 0.498 & 0.419 & 0.344 & 0.276 & 0.217 & 0.167 & 0.127 & 0.096 \\
\hline & 22.4 & 0.906 & 0.875 & 0.836 & 0.788 & 0.730 & 0.662 & 0.588 & 0.509 & 0.430 & 0.354 & 0.285 & 0.224 & 0.174 & 0.133 & 0.100 & 0.075 \\
\hline & 22.6 & 0.880 & 0.842 & 0.795 & 0.739 & 0.673 & 0.599 & 0.520 & 0.441 & 0.364 & 0.294 & 0.233 & 0.180 & 0.138 & 0.104 & 0.078 & 0.058 \\
\hline & 22.8 & 0.848 & 0.803 & 0.747 & 0.683 & 0.610 & 0.532 & 0.452 & 0.375 & 0.304 & 0.241 & 0.187 & 0.143 & 0.109 & 0.081 & 0.060 & 0.045 \\
\hline & 23.0 & 0.810 & 0.756 & 0.692 & 0.621 & 0.543 & 0.464 & 0.386 & 0.313 & 0.249 & 0.194 & 0.149 & 0.113 & 0.085 & 0.063 & 0.047 & 0.034 \\
\hline & 23.2 & 0.764 & 0.702 & 0.631 & 0.554 & 0.475 & 0.397 & 0.323 & 0.258 & 0.202 & 0.155 & 0.118 & 0.088 & 0.066 & 0.049 & 0.036 & 0.026 \\
\hline & 23.4 & 0.711 & 0.642 & 0.566 & 0.486 & 0.408 & 0.333 & 0.267 & 0.209 & 0.161 & 0.123 & 0.092 & 0.069 & 0.051 & 0.038 & 0.028 & 0.020 \\
\hline & 23.6 & 0.652 & 0.577 & 0.498 & 0.419 & 0.344 & 0.276 & 0.217 & 0.167 & 0.128 & 0.096 & 0.072 & 0.053 & 0.039 & 0.029 & 0.021 & 0.015 \\
\hline & 23.8 & 0.588 & 0.509 & 0.430 & 0.354 & 0.285 & 0.225 & 0.174 & 0.133 & 0.100 & 0.075 & 0.055 & 0.041 & 0.030 & 0.022 & 0.016 & 0.012 \\
\hline & 24.0 & 0.520 & 0.441 & 0.364 & 0.294 & 0.233 & 0.180 & 0.138 & 0.104 & 0.078 & 0.058 & 0.043 & 0.031 & 0.023 & 0.017 & 0.012 & 0.009 \\
\hline
\end{tabular}

sex $80 \%$ of all birds correctly according to wing length based on the results of a logistic regression. According to this regression analysis, birds with a wing length $\geq 71 \mathrm{~mm}$ would be male and birds with a wing length of $<71 \mathrm{~mm}$ female. When this split was applied to the data of this study only $60.6 \%$ of all Robins were sexed correctly. Whereas all males were sexed correctly, 37 (92.5\%) out of 40 females were classified as males. 
Table 3 continued

(c) Willow Warbler

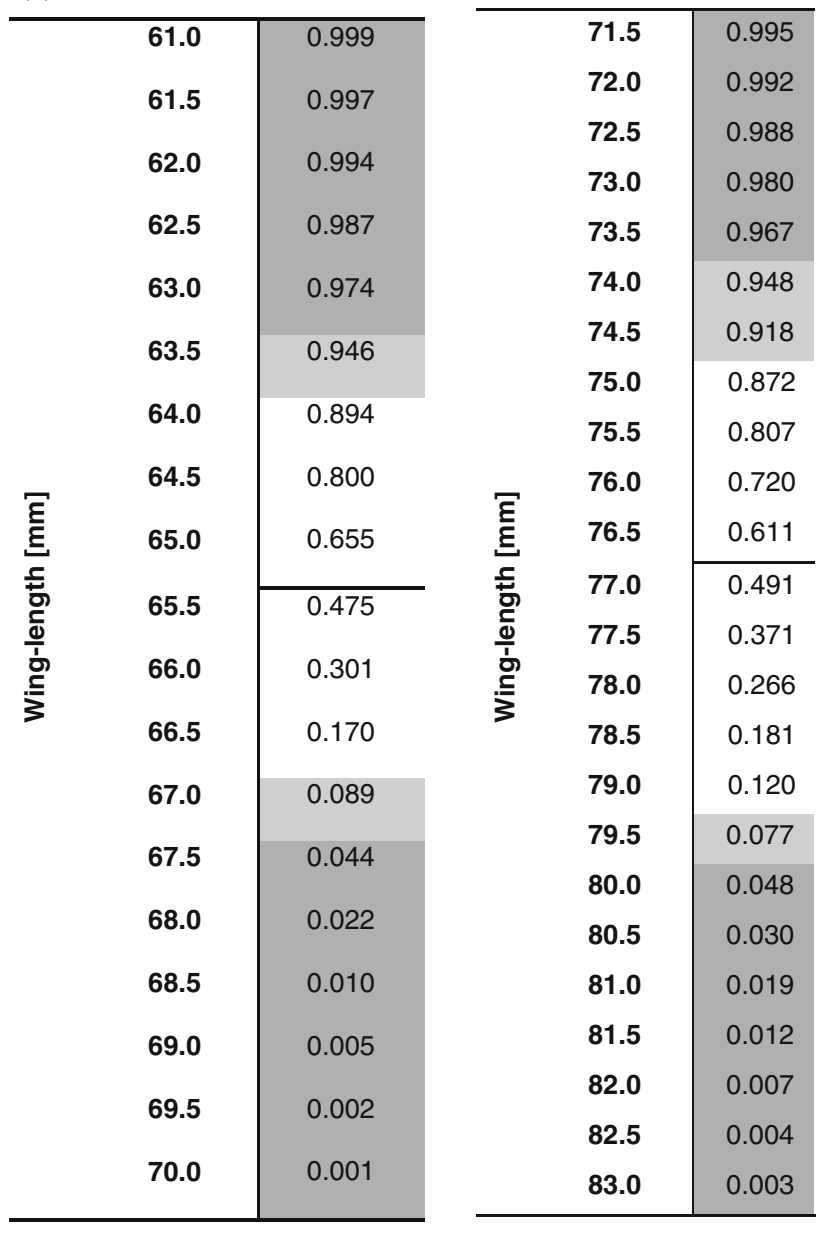

Bold line separates probabilities indicating that a bird is female $(P>0.5)$ or male $(P<0.5)$. Dark grey shading: indicates $>95 \%$ probability of being female $(P>0.95)$ or male $(P<0.05)$. Light grey shading: indicates $\geq 90 \%$ probability of being female $(P>0.900)$ or male $(P \leq 0.100)$

J. Pettersson (cited in Svensson 1992) found that about $60 \%$ of "non-adult" "Fenno-Scandian migrant" Robins could be sexed at Ottenby, Sweden, by using wing length as the sole separation criterion. Birds with a wing length $>74 \mathrm{~mm}$ would be males and birds with a wing length $<71 \mathrm{~mm}$ females, although details for the verification of this character are not given. Applying these characters to the Robins considered here revealed that only 34 out of 94 birds fell within the criteria of Pettersson (in Svensson 1992) including 31 males which were all sexed correctly and 4 females of which one was sexed as a male (wing $75 \mathrm{~mm}$ ). In total, only $35 \%$ of all Robins could be sexed correctly according to the criteria of Pettersson (in Svensson 1992).

Norman (1983) stated he was able to correctly sex $96 \%$ of first year Willow Warblers caught during April to May in northeast England when assuming that males have a wing length of $\geq 65 \mathrm{~mm}$ and females a wing length of $<64 \mathrm{~mm}$. These criteria could be applied to 42 out of 47 Willow Warblers considered in this study of which $90.5 \%$ were sexed correctly. All males (24) were sexed correctly, but 4 out of 23 females were sexed as males and 5 females could not be sexed. When applied to all birds of the study, $80.9 \%$ of all birds could be sexed correctly.

Walton and Walton (1999) studied Reed Buntings between July and December from southeast Scotland using a logistic regression. With the variables wing and mass, $95.4 \%$ of all first year birds could be sexed correctly according to the equation:

$d=132.31-1.33 \times$ wing $-1.58 \times$ mass

if $d<0$ the sex was assigned to be male and if $d>0$ the sex was assigned to be female. Applying this equation to the data of this study, $81.8 \%$ of all birds were sexed correctly. This included $70.8 \%$ of correctly sexed males and $95.0 \%$ of correctly sexed females. Comparing the results of Walton and Walton (1999) with the results of the logistic regression of our analysis revealed that $4.6 \%$ more birds could be classified correctly.

\section{Discussion}

In this study, we investigated whether the sex of five passerine species can be determined with morphological characters. We restricted our analyses to standard measurements because our intention was to apply potential sexseparating characters to the long time series of this study site and possibly to a wide range of ringing stations working with similar standard methodology. The sex of the measured birds was verified with molecular analyses. In the Garden Warbler, sex determination was not possible with the morphological variables applied in this study and the statistical criteria for the inclusion in a logistic regression. In the other four species, a varying number of variables showed significant differences between the sexes. The sex of the latter four species could be determined correctly with the proportion varying from $77.6 \%$ for Reed Warblers to 89.4\% for Willow Warblers with one (Willow Warbler, Reed Bunting) or two (Robin, Reed Warbler) morphological measurements. Therefore, between about 11 and 22\% of the measured birds could not be sexed correctly. It is difficult to assess whether this is accurate enough to be used in further analyses. This question will depend mainly on the questions addressed and on the species considered.

There are several possibilities which may improve the potential application of studies using an approach like the one presented here. First, a repetition of a similar analysis, but applied to a higher number of birds, may improve its 
accuracy. However, on an inter-specific level, a larger number of individuals analysed is not related to a higher proportion of correctly sexed birds. This study included 147 Reed Warblers but only 47 Willow Warblers, but the proportions of correctly sexed birds was 77.6 and $89.4 \%$, respectively. Second, the proportion of correctly sexed birds can be increased when only a subset of the sample is used according to the most discriminating values of the respective morphological variables. When the probability that a bird with certain character values belongs to a certain sex was $>90 \%$, all respective individuals were in fact sexed correctly. Therefore, these combinations of character values could be used to select a subsample of individuals for studies that need to analyse sex-specific traits. This approach may, however, include the caveat that only individuals at the extreme range of certain variables are considered. For example, body size, amongst other factors, may be an indicator of the condition of an individual. In size dimorphic species with, e.g., larger males, an intersexual overlap of characters may lead to the mere consideration of 'large' males and 'small' females, i.e. a preference for the individuals with high condition in one sex over those individuals with low condition in the other sex with consequently spurious results.

The study showed that morphological sex determination according to logistic regression functions could only be applied with care between study sites and generally performs with less accuracy between sites. If all birds of the target species were considered, then the application of morphological characters from other studies performed less well than testing our own data. This may have been for several not mutually exclusive reasons. First, the statistical analysis itself influences the results. In a logistic regression model, variables are selected to best fit the particular dataset. The fit will therefore be less good when a different dataset, either from the same or a different population, is used. This may be the reason for smaller differences as in the application of the criteria of Walton and Walton (1999) to our dataset of Reed Buntings, but we assume that differences in model fit are unlikely to cause the difference in explanatory power of approximately $20 \%$ of the models as in the Robin. Second, inter-ringer variation in measurements may influence the results. The occurrence of interringer variances in standard measurements has been shown in a number of studies (Nisbet et al. 1970; Berthold and Friedrich 1979; Gosler et al. 1998). Nevertheless, assuming that the ringers in all studies were experienced, the differences between the means of the measurements according to internationally standardised methods should be low (Nisbet et al. 1970). Therefore, it seems unlikely that interringer variation in measurements can account for the magnitude of some of the differences of the explanatory power of certain variables between this study and those from other sites (for a possible exception, see below). Third, the inclusion of different age cohorts in the analyses may lead to biased results. It has been shown for many passerine species that first year birds have shorter wings than older birds (e.g. Alatalo et al. 1984; Tiainen and Hanski 1985; Norman 1997). Additionally, it has been discussed that wing length of passerines increases with age (Smith et al. 1986; Dale et al. 2002) and may decrease again in old age (Møller and de Lope 1999). The inclusion of different age cohorts as in the study of Madsen (1997) on Robins could be the reason for the strong sex bias when the discriminating criteria were applied to the birds of our study. However, due to the inclusion of adult Robins into the sample, the mean wing lengths should be longer compared to a sample where only first year birds are considered. Additionally, the same effect should appear if Robins from northern Europe are expected to have longer wings than birds from Central Europe. However, Madsen (1997) noted distinctly shorter mean wing lengths for both sexes (males: $72.2 \pm 1.32 \mathrm{SD}$; females: $69.8 \pm$ $1.54 \pm \mathrm{SD}$ ) than we did in southwestern Germany (Table 1). Madsen's wing length data are also lower than comparable data from Scandinavia (Pettersson 1983). Due to these differences, all males of our study are sexed correctly according to the criteria of Madsen (1997), but the great majority of females are also sexed as males. Although the same measurement technique was used in both studies (method "3" according to Svensson 1992), a ringer bias cannot be excluded. Fourth, birds considered at different sites may differ in their morphology (see, e.g., Hanski and Tiainen 1991 for Willow Warblers). This may either be due to different habitats surrounding the study site as morphology of a number of passerine species has been found to differ between habitats (Lundberg et al. 1981; Michalak 1995; Blondel 2007), or to different migratory behaviour. There are no data on habitat types of the study sites considered, thus this influence cannot be excluded, but Cuadrado (1991) explained the low probability of sexing wintering Robins correctly in Spain with the inclusion of birds with different migratory behaviour into the study. It has been discussed that migration distance is linked with wing length (Leisler and Winkler 2003), and Fiedler (2005) showed on an intra-specific level that Blackcaps with increasing migratory distances have longer wings. Therefore, site-specific morphology as an adaptation to different migratory behaviour is presumably the main reason why morphological sexing cannot be applied over larger geographic scales. Assuming longer wings in populations from more northerly latitudes because of longer migration distances, the wing length which splits the sexes should be higher than in more southern populations and consequently more shorter-winged females should be sexed correctly and more males incorrectly. However, the opposite is the case 
when applying the criteria of Pettersson (in Svensson 1992) and of Norman (1983) to the Robins and the Willow Warblers of this study, respectively. We have no information how the sex of the Robins studied by Pettersson (in Svensson 1992) was verified, which makes it difficult to discuss the differences compared to our study. With respect to Willow Warblers, British birds spend the non-breeding season in West Africa (Wernham et al. 2002) and recoveries of Willow Warblers ringed in southern Germany indicate similar non-breeding areas (Zink 1973). Therefore, the distance of south German Willow Warblers to their non-breeding areas may be even longer compared to British Willow Warblers although the latter breed at higher latitudes. Furthermore, the birds of this study could include some migrants from more northeastern breeding areas with an even longer migration distance.

In conclusion, we showed that in four out of five investigated passerine species the sex could be determined with varying accuracy. For some species, the proportion of correctly sexed individuals was low and may not be sufficient to draw sound inferences when applied to further analyses, e.g. for the investigation of differential migration patterns. Furthermore, it is shown that results from one study site will cause spurious results when applied at another study site for a variety of mutually non-exclusive reasons. As morphology of species at a given site may also vary with time (Nowakowski 2000; Salewski et al. 2009), we recommend the use of morphological sex differentiation methods similar to this study only on a population specific basis, only with one age cohort, and only to birds at the same stage of feather wear (feathers in spring may be more worn compared to feathers in autumn or vice versa) and to adjust the extracted equations from time to time.

\section{Zusammenfassung}

Kriterien zur morphologischen Geschlechtsbestimmung bei Singvögeln sind nicht über größere geographische Räume hinweg anwendbar

Die korrekte Geschlechtsbestimmung von Singvögeln ist für viele Studien erwünscht, aber bei monomorphen Arten oft schwierig. Die Geschlechtsbestimmung anhand morphologischer Merkmale bildet einen guten Ansatz, muss aber anhand anderer Methoden verifiziert werden. Wir prüften bei fünf Singvogelarten mit Hilfe einer logistischen Regression, in der das durch molekulare Methoden bestimmte Geschlecht der untersuchten Vögel als unabhängige Variable einging, ob eine morphologische Geschlechtsbestimmung anhand von Standardmaßen (Flügel-, Feder- und Tarsuslänge, Gewicht) durchgeführt werden kann. Darüber hinaus untersuchten wir, ob durch ähnliche Untersuchungen ermittelte Geschlechtsbestimmungskriterien auch auf die von uns untersuchten Vögel mit gleicher Genauigkeit angewandt werden können. Von den untersuchten Arten ließen sich nur bei der Gartengrasmücke keine morphologischen Variablen ermitteln, die der Geschlechtsbestimmung dienen können. Beim Rotkehlchen konnte bei 87,2\% der Vögel das Geschlecht korrekt bestimmt werden. Für Teichrohrsänger, Fitis und Rohrammer waren die entsprechenden Werte 77,6, 89,4 und 86,4\%. Wenn die Funktion einer logistischen Regression von ähnlichen Studien aus Dänemark und Schottland auf den vorliegenden Datensatz von Rotkehlchen und Rohrammern angewandt wurde, war die Geschlechtsbestimmung in weniger Fällen korrekt als mit der Funktion der eigenen Studie. Das gleiche traf zu, wenn beim Fitis die Flügellänge analog zu einer Studie in Großbritannien zur Geschlechtsbestimmung herangezogen wurde. Für diese Unterschiede gibt es mehrere mögliche Erklärungen: (1) die Regressionsmodelle sind für den Datensatz optimiert, aus dem sie ermittelt wurden, (2) es bestehen Unterschiede in den Messungen verschiedener Beringer, (3) es wurden verschiedene Altersklassen als Grundlage zur Ermittlung morphologischer Unterschiede herangezogen, (4) das Habitat um die jeweiligen Untersuchungsgebiete ist nicht vergleichbar, oder, am wahrscheinlichsten, (5) es bestehen Unterschiede in der Morphologie aufgrund von unterschiedlichem Zugverhalten. Wir empfehlen, dass morphologische Geschlechtsbestimmungen, wie sie in dieser Studie durchgeführt wurden, (1) nur populationsspezifisch angewandt werden, (2) nur eine Altersklasse berücksichtigen sollten und dass (3) die ermittelten Kriterien von Zeit zu Zeit auf fortbestehende Gültigkeit überprüft werden sollten.

Acknowledgments We thank all volunteers at the Mettnau ringing station in 2007 that made this study possible. H.E. thanks J. Martens, Johannes-Gutenberg-University, Mainz, for his support and $\mathrm{H}$. van Noordwijk for help in the laboratory. We thank G. Segelbacher, Greg Conway and an unknown referee for discussing our manuscript. R. Holland kindly improved our English. All work related to the handling of birds (current permit No. 56-8853.17/01, Regierungspräsidium Freiburg) and blood sampling (permit O-05/39a, Regierungspräsidium Freiburg) was done in compliance with German law.

Open Access This article is distributed under the terms of the Creative Commons Attribution Noncommercial License which permits any noncommercial use, distribution, and reproduction in any medium, provided the original author(s) and source are credited.

\section{References}

Alatalo RV, Gustafsson L, Lundberg A (1984) Why do young passerine birds have shorter wings than older birds? Ibis 126:410-415

Bairlein F (1995) Manual of field methods. Wilhelmshaven

Bertellotti M, Tella JL, Godoy JA, Blanco G, Forero MG, Donázar JA, Ceballos O (2002) Determining sex of magellanic penguins 
using molecular procedures and discriminant functions. Waterbirds 25:479-484

Berthold P (1969) Die Laparotomie bei Vögeln. Ein Hilfsmittel zur Geschlechstbestimmung und zur Beobachtung des Gonadenzyklus. Der Zoologische Garten 37:271-279

Berthold P, Friedrich W (1979) Die Federlänge: Ein neues nützliches Flügelmaß. Vogelwarte 30:11-21

Berthold P, Schlenker R (1975) Das "Mettnau-Reit-Illmitz-Programm"- - ein langfristiges Vogelfangprogramm der Vogelwarte Radolfzell mit vielfältiger Fragestellung. Vogelwarte 28:97-123

Blondel J (2007) Coping with habitat heterogeneity: the story of mediterranean blue tits. J Ornithol 148(Suppl 1):S3-S15

Campos F, Hernández M, Arizaga J, Mirando R, Amezcua A (2005) Sex differentiation of corn buntings Miliaria calandra wintering in northern Spain. Ringing Migr 22:159-162

Catry P, Lecoq M, Araújo A, Conway G, Felgueiras M, King JMB, Rumsey S, Salima H, Tenreiro P (2005) Differential migration of chiffchaffs Phylloscopus collybita and P. ibericus in Europe and Africa. J Avian Biol 36:184-190

Cuadrado M (1991) Wing length criteria for sex determination of robins Erithacus rubecula wintering in southern Spain. Ornis Svec 1:55-57

Dale S, Slagsvold T, Lampe HM, Lifjeld JT (2002) Age-related changes in morphological characters in the pied flycatcher Ficedula hypoleuca. Avian Sci 2:153-166

Drost R (1938) Geschlechtsbestimmung lebender Vögel nach der Form der Kloakengegend. Vogelzug 9:102-105

Ellegren H, Fridolfsson A-K (1997) Male-driven evolution of DNA sequences in birds. Nat Genet 17:182-184

Fiedler W (2005) Ecomorphology of the external flight apparatus of blackcaps (Sylvia atricapilla) with different migration behaviour. Ann N Y Acad Sci 1046:253-263

Gosler AG, Greenwood JJD, Baker JK, Davidson NC (1998) The field determination of body size and condition in passerines: a report to the British Ringing Committee. Bird Study 45:92-103

Griffiths R, Double MC, Orr K, Dawson RJG (1998) A DNA test to sex most birds. Mol Ecol 7:1071-1075

Hanski IK, Tiainen J (1991) Morphological variation in sympatric and allopatric populations of European willow warblers and chiffchaffs. Ornis Fenn 68:1-16

Hipkiss T (2007) Can migrating Tengmalm's owls Aegolius funereus be reliably sexed in autumn using simple morphometric measurements? Ringing Migr 23:204-210

Hosmer D, Lemeshov S (1989) Applied logistic regression. Wiley, New York

Jenni L, Winkler R (1994) Moult and ageing of european passerines. Academic, London

Kaiser A (1993) A new multi-category classification of subcutaneous fat deposits of songbirds. J Field Ornithol 64:246-255

Kalchreuter H (1971) Alters- und Geschlechtsbestimmung bei der Rabenkrähe (Corvus corone corone). Vogelwarte 26:106-112

Leisler B, Winkler H (2003) Morphological consequences of migration in passerines. In: Berthold P, Gwinner E, Sonnenschein E (eds) Avian migration. Springer, Berlin, pp 175-186

Lindström A, Hedenström A, Pettersson J (1996) The autumn migration of Willow Warblers Phylloscopus trochilus in Sweden: results from a nation-wide co-operative project. Ornis Svec 6:145-172
Lundberg A, Alatalo RH, Carlson A, Ulfstrand S (1981) Biometry, habitat distribution and breeding success in the pied flycatcher Ficedula hypoleuca. Ornis Scand 12:68-79

Madsen V (1997) Sex-determination of continental European robins Erithacus $r$. rubecula. Bird Study 44:239-244

Markovets ML, Zduniak P, Reuven Y (2008) Differential sex- and age-related migration of bluethroats Luscinia svecica at Eilat, Israel. Naturwissenschaften 95:655-661

Merom K, McCleery RH, Yom-Tov Y (1999) Age related changes in wing-length and body mass in the reed warbler Acrocephalus scirpaceus and clamorous reed warbler $A$. stentoreus. Bird Study 46:249-255

Michalak P (1995) Inter-habitat morphometric differentiation of male willow warblers Phylloscopus trochilus. Ornis Fenn 72:138-139

Møller AP, de Lope F (1999) Senescence in a short-lived migratory bird: age-dependent morphology, migration, reproduction and parasitism. J Anim Ecol 68:163-171

Morgan JH (2005) A computer method for resolving mixed normal distributions. Ringing Migr 22:145-153

Nisbet ICT, Baird J, Howard DV, Anderson KS (1970) Statistical comparison of wing-lengths measured by four observers. Bird Banding 41:307-308

Norman SC (1983) Variations in wing-lengths of willow warblers in relation to age, sex and season. Ringing Migr 4:269-274

Norman SC (1997) Juvenile wing shape, wing moult and weight in the family sylviidae. Ibis 139:617-630

Nowakowski JJ (2000) Long-term variability of wing length in a population of the reed warbler Acrocephalus scirpaceus. Acta Ornithol 35:173-182

Ottvall R, Gunnarsson G (2007) Morphological and molecular sex identification of redshanks Tringa totanus. Bird Study 54:127-129

Pettersson J (1983) Rödhakens Erithacus rubecula höstflyttning vid Ottenby. Vår Fågelvärld 42:333-342

Salewski V, Hochachka W, Fiedler W (2009) Global warming and Bergmann's rule: do central European passerines adjust their body size to rising temperatures? Oecologia. doi: $10.1007 / \mathrm{s} 00442-009-1446-2$ (in press)

Schmitz P, Steiner F (2006) Autumn migration of reed buntings Emberiza schoeniclus in Switzerland. Ringing Migr 23:33-38

Shealer DA, Clearey CM (2007) Sex determination of adult black terns by DNA and morphometrics: tests of sample size, temporal stability and geographic specificity in the classification accuracy of discriminant function models. Waterbirds 30:180-188

Smith JNM, Arcese P, Schluter D (1986) Song sparrows grow and shrink with age. Auk 103:210-212

Svensson L (1992) Identification guide to European passerines. Stockholm

Tiainen J, Hanski IK (1985) Wing shape variation of finnish and central European willow warblers Phylloscopus trochilus and Chiffchaffs $P$. collybita. Ibis 127:365-371

Walton C, Walton P (1999) Sexing first year reed buntings Emberiza schoeniclus using biometrics. Ringing Migr 19:327-331

Wernham C, Toms M, Marchant J, Clark J, Sirirwardena G, Baillie S (2002) The migration atlas-movements of the birds of Britain and Ireland. T \& AD Poyser, London

Zink G (1973) Der Zug europäischer Singvögel I, 1. Vogelwarte Radolfzell, Radolfzell 